\title{
Risk Factors of Type 1 Diabetes Mellitus in Children Attending Aswan University Hospital
}

Asmaa Mohammed Ismail, Ahmed El-Meshwady Ahmed Mohammed*, Hanan Mohammed Abd El-Moneim

Department of Pediatrics, Faculty of Medicine, Aswan University

*Corresponding author: Ahmed El-Meshwady Ahmed Mohammed, Mobile: (+20) 01000507267,

E-Mail: ahmed.elmeshwady1992@gmail.com

\begin{abstract}
Background: Type 1 diabetes (T1DM) is a chronic disease caused by immune-mediated destruction of insulin producing beta cells in the pancreas. The destruction of beta cells results in insulin insufficiency, and patients develop life-threatening hyperglycemia that clinically manifests with weight loss, polyuria, and polydipsia.

Objective: This study aimed to search for disease prediction and disease prevention.

Patients and methods: The present cross-sectional study was conducted at Aswan University Hospital. One hundred children with T1DM were included during the period from April to November 2018. The mean age of the included patients was $7.2 \pm 4.3$ years and the age at onset of the disease was $4.56 \pm 2.9$ years. $56 \%$ of the patients were males.

Results: In our cohort, we found that, in terms of obstetric history, $76 \%$ of the mothers delivered by CS and $12 \%$ of them had history of preeclampsia. $13 \%$ had a history of gestational diabetes. On the other hand, $13 \%$ and $29 \%$ of the mothers had a history of infectious diseases and use of antibiotics, respectively. There were no statistically significant associations between age group and preeclampsia $(\mathrm{p}=0.33)$, gestational diabetes and use of insulin $(\mathrm{p}$ $=0.67)$, infectious diseases $(p=0.91)$, use of antibiotic $(p=0.26)$, use of antihypertensives $(p=0.22)$, and mode of delivery $(\mathrm{p}=0.067)$.

Conclusion: In conclusion, Egyptian children with T1DM had wide range of genetics, environmental, maternal, and neonatal risk factors that may have contributed to the development of T1DM.
\end{abstract}

Keywords: Type 1 Diabetes Mellitus, Children, Aswan University Hospital.

\section{INTRODUCTION}

Among Eastern Mediterranean and Middle Eastern countries, the largest contribution to the total number of estimated childhood type 1 diabetes mellitus (T1DM) cases comes from Egypt which accounts for about a quarter of the region's total. The incidence varies between $1 / 100 \quad 000$ per year (Pakistan) and 8/100 000 per year (Egypt) in children under the age of 15 years ${ }^{(1)}$.

Type 1 diabetes (T1D) is an autoimmune disorder which affects millions around the world. The incidence of T1D in children is increasing worldwide at a rate that cannot be explained by genetics alone ${ }^{(2)}$. Type 1 diabetes mellitus (T1DM) is a chronic autoimmune disease resulting in the designated immune destruction of insulin producing $\beta$-cells, usually diagnosed in youth, and associated with important psychological, familial, and social disorders (3)

Environmental triggers such as certain dietary factors and viruses are thought to initiate the autoimmune process, leading to the destruction of pancreatic B-cell and consequent T1DM. A genetic predisposition is another pre-requisite, allowing the autoimmune process to progress ${ }^{(4)}$.

Persons destined to develop type 1 diabetes are assumed to begin life with a full capacity of $\beta$ cells. However, a "triggering" insult, likely environmental, initiates a process involving the recruitment of antigen-presenting cells. Antigenpresenting cells sequester self-antigens released by injured $\beta$-cells, followed by their transport to pancreatic lymph nodes where they are subsequently presented to auto reactive $\mathrm{T}$ cells ${ }^{(5)}$.

Type 1 diabetes may be diagnosed at nearly any age, though peaks in presentation occur between ages of 5 to 7 and around puberty. There appears to be seasonal variation with more cases diagnosed in winter. Unlike most autoimmune disorders, type 1 diabetes is slightly more common in boys and men. Insufficient endogenous insulin leads to hyperglycemia, hyperglucagonemia, glycosuria, and without treatment, eventually ketosis, acidosis, dehydration, and death. About one-third of patients with newly-diagnosed type 1 diabetes present with diabetic ketoacidosis (DKA) which has a mortality rate of around $0.5 \%$, despite aggressive treatment ${ }^{(6)}$.

There is a growing evidence that the underlying mechanisms in the pathogenesis of diabetic complications include certain genetic and epigenetic modifications, nutritional factors, and sedentary lifestyle ${ }^{(7)}$. Maternal age $>35$ years at delivery, the presence of gestational diabetes, pre-eclampsia and taking medications during pregnancy were significantly associated with the occurrence of T1DM. In addition, low birth weight children $(<2500$ grams $)$ and those who suffered from neonatal diseases (respiratory distress, jaundice, and infection) were at 
increased risk of T1DM. Consumption of cow's milk during the1st year of life was a significant predictor for developing T1DM. However, vitamin D supplement and increased duration of breast feeding were significant protective factors ${ }^{(\mathbf{8})}$.

The purpose of this study was disease prediction and disease prevention. Prevention of T1DM could be achieved by avoiding those environmental factors which cause the disease or modifying the destructive process before the onset of clinical manifestations.

\section{PATIENTS AND METHODS}

The present cross-sectional study was conducted at Aswan University Hospital. One hundred children with T1DM were included during the period from April to November 2018. In addition, 100 ageand sex-matched volunteers were included as control group.

\section{The T1DM cases were divided into 4 groups:}

- Group I: Infants and toddlers (AGE: one moth - 2 year).

- Group II: Preschool age children (AGE 3-5 years).

- Group III: Middle childhood children (AGE 6-10 years).

- Group IV: Adolescences (AGE 11-18 years).

Ethical Statement: The present study run in concordance with International Ethical Standards and applicable local regulatory guidelines. A written informed consent was obtained from the parents of every eligible patient. Parents were informed about the study objectives, methodology, risk, and benefit.

The study's protocol was reviewed and approved by the Institutional Review Board (IRB), Ethics Committee or Audit Department of Faculty of Medicine, Aswan University.

Inclusion criteria: Diagnosed Type 1 diabetic children with age of one month to age of 18 year old and attending pediatric Outpatient Endocrine Clinic and Emergency Room (ER) Unite in Aswan University Hospitals.

Exclusion criteria: Type 2 diabetes mellitus (T2DM) and diabetes secondary to post-surgical pancreatectomy, cystic fibrosis and steroid therapy.

Sample size and sampling: We utilized nonprobability consecutive sampling technique. A total of 100 children were determined to be included in the present study.

\section{Data Collection:}

All included patients were interviewed and data were collected in the form of structured questionnaire that was filled from parents or caregivers of the included children. The questionnaire includes the following data:

1-Full history taking: Child sex, Age and Residency. Consanguinity of parents. Family history of T1DM or
T2DM. History of gestational diabetes. Similar cases in the family. Birth weight. Natal, postnatal and developmental history. Vaccination history. History of upper respiratory tract infections and gastroenteritis preceding presentation. Type of infant feeding (breast fed or formula fed). History of cow milk introduction before age of one year. History of associated diseases (e.g. autoimmune diseases...)

In addition to: Age of onset of diabetes. Presenting symptoms (polyuria, polydipsia, weight loss, diabetic ketoacidosis) and history of hospital admission and insulin dose.

2- Full physical examination and some anthropometric measurements (weight $\&$ height).

3-Laboratory investigations including complete blood count, random blood glucose, glycosylated hemoglobin (HbA1C), lipid profiles, thyroid function, urine analysis and fundus examination.

\section{Study's Outcomes:}

The primary outcome in the present study was to determine the prevalence of maternal, neonatal, environmental, and nutritional risk factors among children with T1DM. The secondary objective of the present study was to assess the association between those risk factors and age groups.

\section{Statistical Analysis}

An Excel spreadsheet was established for the entry of data. We used validation checks on numerical variables and option-based data entry method for categorical variables to reduce potential errors. The analyses were carried with SPSS software (Statistical Package for the Social Sciences, version 24, SSPS Inc, Chicago, IL, USA). The normality of the data were assessed using Shapiro-Wilk Test. Numerical data were described as mean \pm SD if normally distributed, or median and interquartile range [IQR] if not normally distributed. Frequency tables with percentages were used for categorical variables. Independent Student t-test and paired t-test were used to compare parametric quantitative variables, while Mann-Whitney tests and Wilcoxon matched pairs test were used to compare non-parametric quantitative variables. Chi-square test or McNemar-Bowker tests were used to analyze categorical variables. Multilinear logistic regression was undertaken to assess the predictors of mortality. A p-value $\leq 0.05$ is considered statistically significant.

\section{RESULTS}

The present study was a cross-sectional study that included 100 children with T1DM who were recruited from Aswan University Hospitals over a period of six months from April to November 2018. In addition, 100 age- and sex-matched volunteers as control group. The mean age of the included patients was $7.2 \pm 4.3$ years and the majority of them middle-aged children (40\%). $56 \%$ of the patients were males (Table 1 ). 
Table (1): The demographic characteristics of the included patients

\begin{tabular}{|c|c|c|c|}
\hline Variables & Patients $(\mathrm{N}=100)$ & Controls $(\mathrm{N}=100)$ & P-value \\
\hline $\begin{array}{l}\text { Age in years } \\
\text { Mean } \pm \text { SD } \\
\text { Median (range) } \\
\end{array}$ & $\begin{array}{l}7.2 \pm 4.3 \\
7(1-14) \\
\end{array}$ & $\begin{array}{l}7.5 \pm 3.3 \\
7(1-14)\end{array}$ & 0.66 \\
\hline $\begin{array}{l}\text { Gender, No. (\%) } \\
\text { Male } \\
\text { Female }\end{array}$ & $\begin{array}{l}56(56 \%) \\
44(44 \%)\end{array}$ & $\begin{array}{l}50(50 \%) \\
50(50 \%)\end{array}$ & 0.72 \\
\hline $\begin{array}{l}\text { Age Category, No. (\%) } \\
\text { Infants } \\
\text { Preschool } \\
\text { Middle Age } \\
\text { Adolescent }\end{array}$ & $\begin{array}{l}20(20 \%) \\
14(14 \%) \\
40(40 \%) \\
26(26 \%)\end{array}$ & $\begin{array}{l}14(14 \%) \\
14(14 \%) \\
46(46 \%) \\
26(26 \%)\end{array}$ & 0.32 \\
\hline
\end{tabular}

*Data are presented as mean $\pm \mathrm{SD}$, median (Range), or number (\%)

Table (1) showed the demographic characteristics of the included patients. There were no significant differences between studied groups in terms of age $(p=0.66)$ or gender $(p=0.72)$.

Table (2): Relation between age of the included patients and family history

\begin{tabular}{|c|c|c|c|c|c|}
\hline Variables & $\begin{array}{l}\text { Infants } \\
(\mathbf{N}=20)\end{array}$ & $\begin{array}{c}\text { Preschool } \\
(\mathrm{N}=14)\end{array}$ & $\begin{array}{c}\text { Middle-aged } \\
(\mathrm{N}=40)\end{array}$ & $\begin{array}{c}\text { Adolescent } \\
(\mathbf{N}=26)\end{array}$ & P-value \\
\hline \begin{tabular}{|ll} 
& Family history of T1DM, No. \\
& $(\boldsymbol{\%})$ \\
- & Yes \\
- & No \\
\end{tabular} & $\begin{array}{c}5(25 \%) \\
15(75 \%) \\
\end{array}$ & $\begin{array}{c}4(26.7 \%) \\
10(73.3 \%) \\
\end{array}$ & $\begin{array}{l}10(25 \%) \\
30(75 \%) \\
\end{array}$ & $\begin{array}{c}1(3.9 \%) \\
25(96.7 \%) \\
\end{array}$ & 0.03 \\
\hline $\begin{array}{ll} & \text { Family history of T2DM, No. } \\
(\boldsymbol{\%}) \\
-\quad \text { Yes } \\
-\quad \text { No }\end{array}$ & $\begin{array}{c}11(55 \%) \\
9(45 \%)\end{array}$ & $\begin{array}{l}8(57.1 \%) \\
6(42.9 \%)\end{array}$ & $\begin{array}{l}27(67.5 \%) \\
13(32.5 \%)\end{array}$ & $\begin{array}{l}13(50 \%) \\
13(50 \%)\end{array}$ & 0.52 \\
\hline 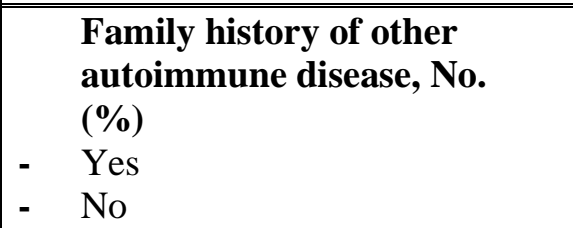 & $\begin{array}{l}10(50 \%) \\
10(50 \%)\end{array}$ & $\begin{array}{l}6(42.8 \%) \\
8(57.2 \%)\end{array}$ & $\begin{array}{l}19(47.5 \%) \\
21(52.5 \%)\end{array}$ & $\begin{array}{l}12(46.2 \%) \\
14(53.8 \%)\end{array}$ & 0.98 \\
\hline $\begin{array}{ll} & \text { Consanguinity, No. (\%) } \\
- & \text { Yes } \\
- & \text { No }\end{array}$ & $\begin{array}{c}3(15 \%) \\
17(85 \%)\end{array}$ & $\begin{array}{l}5(35.7 \%) \\
9(64.3 \%)\end{array}$ & $\begin{array}{l}17(42.5 \%) \\
23(56.5 \%)\end{array}$ & $\begin{array}{c}8(30.8 \%) \\
18(69.2 \%)\end{array}$ & $<0.001$ \\
\hline
\end{tabular}

$*$ Data are presented as mean $\pm \mathrm{SD}$, median (Range), or number $(\%)$

Table (2) showed that there were statistically significant associations between age group and family history of T1DM ( $p<0.001)$ and consanguinity $(\mathrm{p}<0.001)$. In contrary, there were no statistically significant associations between age group and T2DM $(\mathrm{p}=0.52)$ and history of other autoimmune diseases $(\mathrm{p}=0.98)$. 
Table (3): Relation between age of the included patients and maternal risk factors

\begin{tabular}{|c|c|c|c|c|c|}
\hline Variables & $\begin{array}{l}\text { Infants } \\
(\mathbf{N}=\mathbf{2 0})\end{array}$ & $\begin{array}{c}\begin{array}{c}\text { Preschool (N } \\
=14)\end{array} \\
\end{array}$ & $\begin{array}{c}\text { Middle-aged ( } N \\
=40)\end{array}$ & $\begin{array}{c}\text { Adolescent }(\mathrm{N} \\
=26)\end{array}$ & P-value \\
\hline $\begin{array}{ll} & \text { Coffee Consumption, } \\
& \text { No. }(\%) \\
- & \text { Yes } \\
- & \text { No } \\
\end{array}$ & $\begin{array}{l}12(60 \%) \\
8(40 \%) \\
\end{array}$ & $\begin{array}{c}10(71.4 \%) \\
4(28.6 \%) \\
\end{array}$ & $\begin{array}{l}24(60 \%) \\
16(40 \%) \\
\end{array}$ & $\begin{array}{c}17(65.4 \%) \\
9(34.6 \%) \\
\end{array}$ & 0.86 \\
\hline $\begin{array}{ll} & \text { Preeclampsia, No. }(\%) \\
- & \text { Yes } \\
- & \text { No }\end{array}$ & $\begin{array}{c}0 \\
20(100 \%)\end{array}$ & $\begin{array}{c}3(21.4 \%) \\
11(78.6 \%)\end{array}$ & $\begin{array}{c}7(17.5 \%) \\
33(82.5 \%)\end{array}$ & $\begin{array}{c}2(7.7 \%) \\
24(92.3 \%)\end{array}$ & 0.33 \\
\hline $\begin{array}{ll} & \text { Gestational Diabetes, } \\
& \text { No. }(\%) \\
- & \text { Yes } \\
- & \text { No } \\
\end{array}$ & $\begin{array}{c}4(20 \%) \\
16(80 \%) \\
\end{array}$ & $\begin{array}{c}2(14.3 \%) \\
12(85.7 \%) \\
\end{array}$ & $\begin{array}{c}5(12.5 \%) \\
35(87.2 \%) \\
\end{array}$ & $\begin{array}{c}2(7.7 \%) \\
24(92.3 \%) \\
\end{array}$ & 0.67 \\
\hline $\begin{array}{ll} & \text { Infectious Diseases, } \\
& \text { No. }(\%) \\
-\quad & \text { Yes } \\
- & \text { No } \\
\end{array}$ & $\begin{array}{c}3(15 \%) \\
17(85 \%) \\
\end{array}$ & $\begin{array}{c}1(7.1 \%) \\
13(92.9 \%) \\
\end{array}$ & $\begin{array}{c}5(12.5 \%) \\
35(87.2 \%) \\
\end{array}$ & $\begin{array}{c}3(11.5 \%) \\
23(89.5 \%) \\
\end{array}$ & 0.91 \\
\hline $\begin{array}{ll} & \text { Use of Antibiotics, No. } \\
& (\%) \\
- & \text { Yes } \\
- & \text { No } \\
\end{array}$ & $\begin{array}{l}11(55 \%) \\
9(44 \%)\end{array}$ & $\begin{array}{c}3(21.4 \%) \\
11(78.6 \%)\end{array}$ & $\begin{array}{l}16(40 \%) \\
24(60 \%)\end{array}$ & $\begin{array}{c}9(34.6 \%) \\
15(74.4 \%)\end{array}$ & 0.26 \\
\hline $\begin{array}{ll} & \text { Use of Insulin, No. (\%) } \\
- & \text { Yes } \\
- & \text { No } \\
\end{array}$ & $\begin{array}{c}4(20 \%) \\
16(80 \%) \\
\end{array}$ & $\begin{array}{c}2(14.3 \%) \\
12(85.7 \%) \\
\end{array}$ & $\begin{array}{c}5(12.5 \%) \\
35(87.2 \%) \\
\end{array}$ & $\begin{array}{c}2(7.7 \%) \\
24(92.3 \%) \\
\end{array}$ & 0.67 \\
\hline $\begin{array}{ll} & \text { Use of Antiemetic, No. } \\
& (\%) \\
- & \text { Yes } \\
- & \text { No } \\
\end{array}$ & $\begin{array}{c}5(25 \%) \\
15(75 \%) \\
\end{array}$ & $\begin{array}{c}11(78.6 \%) \\
3(21.4 \%) \\
\end{array}$ & $\begin{array}{c}36(90 \%) \\
4(105) \\
\end{array}$ & $\begin{array}{c}21(80.7 \%) \\
5(19.3 \%) \\
\end{array}$ & 0.26 \\
\hline $\begin{array}{ll} & \text { Use of } \\
\text { Antihypertensive, No. } \\
(\%) \\
-\quad \text { Yes } \\
-\quad \text { No } \\
\end{array}$ & $\begin{array}{c}4(20 \%) \\
16(80 \%)\end{array}$ & $\begin{array}{l}7(50 \%) \\
7(50 \%)\end{array}$ & $\begin{array}{l}18(45 \%) \\
22(55 \%)\end{array}$ & $\begin{array}{l}11(42.3 \%) \\
15(57.7 \%)\end{array}$ & 0.22 \\
\hline $\begin{array}{ll} & \begin{array}{l}\text { Mode of delivery, No. } \\
(\%)\end{array} \\
- & \text { CS } \\
- & \text { NVD } \\
\end{array}$ & $\begin{array}{l}15(75 \%) \\
5(25 \%)\end{array}$ & $\begin{array}{c}14(100 \%) \\
0\end{array}$ & $\begin{array}{l}24(60 \%) \\
16(40 \%)\end{array}$ & $\begin{array}{c}21(80.7 \%) \\
5(19.3 \%)\end{array}$ & 0.067 \\
\hline
\end{tabular}

*Data are presented as mean \pm SD, median (Range), or number (\%)

Table (3) showed the relation between age of the included patients and maternal risk factors. There were no statistically significant associations between age group and coffee consumption $(\mathrm{p}=0.86)$, preeclampsia $(\mathrm{p}=0.33)$, gestational diabetes and use of insulin $(\mathrm{p}=0.67)$, infectious diseases $(\mathrm{p}=0.91)$, use of antibiotic $(\mathrm{p}=0.26)$, use of antihypertensive $(\mathrm{p}=0.22)$, and mode of delivery $(\mathrm{p}=0.067)$. 
Table (4): Neonatal risk factors of the included patients

\begin{tabular}{|c|c|c|c|c|c|}
\hline Variables & $\begin{array}{l}\text { Infants } \\
(\mathrm{N}=\mathbf{2 0})\end{array}$ & $\begin{array}{c}\text { Preschool } \\
(\mathrm{N}=14)\end{array}$ & $\begin{array}{c}\text { Middle-aged (N } \\
=40)\end{array}$ & $\begin{array}{c}\text { Adolescent }(\mathrm{N}= \\
26)\end{array}$ & $\overline{P \text { P-value }}$ \\
\hline $\begin{array}{ll} & \text { Preterm, No. (\%) } \\
- & \text { Yes } \\
- & \text { No } \\
\end{array}$ & $\begin{array}{c}4(20 \%) \\
16(80 \%) \\
\end{array}$ & $\begin{array}{c}3(21.4 \%) \\
11(78.6 \%)\end{array}$ & $\begin{array}{c}6(15 \%) \\
34(87.2 \%) \\
\end{array}$ & $\begin{array}{c}2(7.7 \%) \\
24(92.3 \%) \\
\end{array}$ & 0.58 \\
\hline 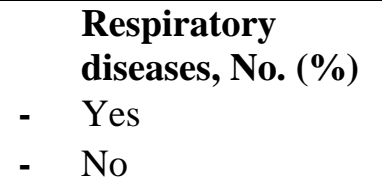 & $\begin{array}{c}11(55 \%) \\
9(45 \%)\end{array}$ & $\begin{array}{l}8(51.4 \%) \\
6(48.6 \%)\end{array}$ & $\begin{array}{l}24(60 \%) \\
16(40 \%)\end{array}$ & $\begin{array}{c}17(65.4 \%) \\
9(34.6 \%)\end{array}$ & 0.9 \\
\hline $\begin{array}{ll} & \text { Jaundice, No. (\%) } \\
-\quad & \text { Yes } \\
- & \text { No } \\
\end{array}$ & $\begin{array}{c}16(80 \%) \\
4(20 \%) \\
\end{array}$ & $\begin{array}{c}13(92.9 \%) \\
1(7.1 \%) \\
\end{array}$ & $\begin{array}{c}32(80 \%) \\
8(20 \%) \\
\end{array}$ & $\begin{array}{c}19(73.1 \%) \\
7(26.9 \%) \\
\end{array}$ & 0.52 \\
\hline $\begin{array}{ll} & \text { Infectious } \\
& \text { Diseases, No. (\%) } \\
-\quad & \text { Yes } \\
- & \text { No }\end{array}$ & $\begin{array}{l}10(50 \%) \\
10(50 \%)\end{array}$ & $\begin{array}{l}8(51.4 \%) \\
6(48.6 \%)\end{array}$ & $\begin{array}{l}18(45 \%) \\
22(55 \%)\end{array}$ & $\begin{array}{c}9(34.6 \%) \\
17(65.4 \%)\end{array}$ & 0.53 \\
\hline
\end{tabular}

*Data are presented as mean \pm SD, median (Range), or number (\%)

Table (4) showed the neonatal risk factors of the included patients. There were no statistically significant associations between age group and preterm $(p=0.58)$, respiratory diseases $(p=0.9)$, jaundice $(p=0.52)$, infectious diseases ( $p=0.91)$, use of antibiotic $(p=0.26)$, use of antihypertensive $(p=0.22)$, and infectious diseases $(p=0.53)$.

Table (5): Environmental risk factors of the included patients

\begin{tabular}{|c|c|c|c|c|c|}
\hline Variables & $\begin{array}{l}\text { Infants } \\
(\mathrm{N}=\mathbf{2 0})\end{array}$ & $\begin{array}{c}\text { Preschool } \\
(\mathrm{N}=14)\end{array}$ & $\begin{array}{c}\begin{array}{c}\text { Middle-aged } \\
(\mathrm{N}=\mathbf{4 0})\end{array} \\
\end{array}$ & $\begin{array}{c}\begin{array}{c}\text { Adolescent } \\
(\mathbf{N}=\mathbf{2 6})\end{array} \\
\end{array}$ & P-value \\
\hline $\begin{array}{ll} & \text { Measles, No. (\%) } \\
- & \text { Yes } \\
- & \text { No } \\
\end{array}$ & $\begin{array}{c}1(5 \%) \\
19(95 \%)\end{array}$ & $\begin{array}{c}1(7.1 \%) \\
13(92.9 \%)\end{array}$ & $\begin{array}{c}5(12.5 \%) \\
35(87.2 \%)\end{array}$ & $\begin{array}{c}2(7.7 \%) \\
24(92.3 \%)\end{array}$ & 0.77 \\
\hline $\begin{array}{ll} & \text { Varicella, No. (\%) } \\
-\quad & \text { Yes } \\
- & \text { No } \\
\end{array}$ & \begin{tabular}{|c|}
$2(10 \%)$ \\
$18(90 \%)$ \\
\end{tabular} & $\begin{array}{l}2(14.3 \%) \\
12(85.7 \%)\end{array}$ & $\begin{array}{c}5(12.5 \%) \\
35(87.5 \%) \\
\end{array}$ & $\begin{array}{c}4(15.4 \%) \\
22(84.5 \%)\end{array}$ & 0.95 \\
\hline $\begin{array}{ll} & \text { Mumps, No. (\%) } \\
- & \text { Yes } \\
- & \text { No } \\
\end{array}$ & $\begin{array}{c}5(25 \%) \\
15(75 \%) \\
\end{array}$ & $\begin{array}{l}4(26.7 \%) \\
10(73.3 \%) \\
\end{array}$ & $\begin{array}{l}10(25 \%) \\
30(75 \%) \\
\end{array}$ & $\begin{array}{c}1(3.9 \%) \\
25(96.7 \%) \\
\end{array}$ & 0.03 \\
\hline $\begin{array}{ll} & \text { Thyroid diseases, No. (\%) } \\
- & \text { Yes } \\
- & \text { No }\end{array}$ & $\begin{array}{l}4(20 \%) \\
16(80 \%)\end{array}$ & $\begin{array}{l}4(26.7 \%) \\
10(73.3 \%)\end{array}$ & $\begin{array}{c}9(22.5 \%) \\
31(77.5 \%)\end{array}$ & $\begin{array}{c}2(7.7 \%) \\
24(92.3 \%)\end{array}$ & 0.34 \\
\hline $\begin{array}{ll} & \text { Asthma, No. (\%) } \\
- & \text { Yes } \\
- & \text { No } \\
\end{array}$ & $\begin{array}{c}3(15 \%) \\
17(85 \%) \\
\end{array}$ & $\begin{array}{c}1(7.1 \%) \\
13(92.9 \%)\end{array}$ & $\begin{array}{c}5(12.5 \%) \\
35(87.2 \%) \\
\end{array}$ & $\begin{array}{c}2(7.7 \%) \\
24(92.3 \%) \\
\end{array}$ & 0.91 \\
\hline $\begin{array}{ll} & \text { Eczema, No. (\%) } \\
- & \text { Yes } \\
- & \text { No }\end{array}$ & $\begin{array}{l}4(20 \%) \\
16(80 \%)\end{array}$ & $\begin{array}{l}2(14.3 \%) \\
12(85.7 \%)\end{array}$ & $\begin{array}{c}5(12.5 \%) \\
35(87.2 \%)\end{array}$ & $\begin{array}{c}2(7.7 \%) \\
24(92.3 \%)\end{array}$ & 0.67 \\
\hline
\end{tabular}

*Data are presented as mean \pm SD, median (Range), or number (\%)

Table (5) showed the environmental risk factors of the included patients. There were no statistically significant associations between age group and measles $(\mathrm{p}=0.77)$, varicella $(\mathrm{p}=0.95)$, thyroid diseases $(\mathrm{p}=0.34)$, asthma $(\mathrm{p}$ $=0.91)$, and eczema $(p=0.67)$. In contrary, there was statistically significant associations between age group and mumps ( $\mathrm{p}=0.03$ ). 
Table (6): Nutritional risk factors of the included patients

\begin{tabular}{||l|c|c|c|c|c||}
\hline \multicolumn{1}{|c|}{ Variables } & $\begin{array}{c}\text { Infants } \\
(\mathbf{N = 2 0})\end{array}$ & $\begin{array}{c}\text { Preschool } \\
(\mathbf{N}=\mathbf{1 4})\end{array}$ & $\begin{array}{c}\text { Middle-aged (N } \\
\mathbf{= 4 0})\end{array}$ & $\begin{array}{c}\text { Adolescent } \\
(\mathbf{N}=\mathbf{2 6})\end{array}$ & P-value \\
\hline \hline Vitamin D supplementation, & & & & & \\
No. (\%) & & & & & \\
-Yes & $17(85 \%)$ & $9(64.3 \%)$ & $22(55 \%)$ & $15(57.7 \%)$ & 0.77 \\
-No & $3(15 \%)$ & $5(35.7 \%)$ & $18(45 \%)$ & $7(42.3 \%)$ & \\
\hline \hline Cow milk before 1 year, No. & & & & & \\
(\%) & $15(75 \%)$ & $10(71.45)$ & $35(87.5 \%)$ & $20(76.9 \%)$ & 0.47 \\
-Yes & $5(25 \%)$ & $4(28.6 \%)$ & $5(12.5 \%)$ & $6(23.1 \%)$ & \\
-No & & & & \\
\hline
\end{tabular}

*Data are presented as mean \pm SD, median (Range), or number (\%).

Table (6) showed the nutritional risk factors of the included patients. There were no statistically significant associations between age group and vitamin $\mathrm{D}$ supplementation $(\mathrm{p}=0.77)$ and introduction of cow milk before 1 year $(\mathrm{p}=0.47)$.

Table (7): Vaccination of the included patients

\begin{tabular}{||l|c|c|c|c|c|}
\hline \multicolumn{1}{|c|}{ Variables } & $\begin{array}{c}\text { Infants } \\
(\mathbf{N}=\mathbf{2 0})\end{array}$ & $\begin{array}{c}\text { Preschool } \\
(\mathbf{N}=\mathbf{1 4})\end{array}$ & $\begin{array}{c}\text { Middle-aged } \\
(\mathbf{N}=\mathbf{4 0})\end{array}$ & $\begin{array}{c}\text { Adolescent } \\
(\mathbf{N}=\mathbf{2 6})\end{array}$ & P-value \\
\hline \hline $\begin{array}{l}\text { Vaccination, No. (\%) } \\
\text { Updated }\end{array}$ & $9(95 \%)$ & $\begin{array}{c}12(85.7 \%) \\
2(14.3 \%)\end{array}$ & $\begin{array}{c}38(95 \%) \\
2(5)\end{array}$ & $\begin{array}{c}24(92.3 \%) \\
2(7.7 \%)\end{array}$ & 0.77 \\
\hline
\end{tabular}

*Data are presented as mean \pm SD, median (Range), or number $(\%)$

Table (7) showed the vaccination of the included patients. There was no statistically significant association between age group and vaccination $(\mathrm{p}=0.77)$

\section{DISCUSSION}

In our study, the mean age of the included patients was 7.2 \pm 4.3 years and the age at onset of the disease was $4.56 \pm 2.9$ years. $56 \%$ of the patients were males. We conducted the present study in order to describe the clinical characteristics, laboratory findings and the different risk factors in children who developed T1DM. Large registries in both Europe and the United States show that the incidence of T1D peaks between 5 to 7 years of age and again when children enter puberty. Unlike most autoimmune diseases, T1D is more common in males than females (9). In line with our findings, Al-Yaarubi and colleagues ${ }^{(\mathbf{1 0 )})}$ who performed a retrospective analysis of all children with T1DM attending the Pediatric Endocrine Unit at Sultan Qaboos University Hospital, Oman from June 2006 to May 2013. One hundred and forty-four patients were included in the study. The mean age at diagnosis was $6.7 \pm 3.7$ years and $52 \%$ of them were males. Likewise, El-Ziny and colleagues (1) included all T1DM patients aged 0-18 years who lived in the Nile Delta region of Egypt and who were either diagnosed at or referred to Mansoura University Children's Hospital (MUCH) between 1 January 1994 and 31 December 2011. From a total of 1600 T1DM patients, $891(55.7 \%)$ were males and the majority of the patients aged 6-10 years old.

Regarding the disease characteristics, we found that the most common presentation was polyuria/polydipsia, followed by weight loss, nocturia, and vomiting. In addition, the mean $\mathrm{HbA} 1 \mathrm{c}$ level was $11.28 \pm 2.3 \%$. Similar to our findings, Stipancic and colleagues ${ }^{(11)}$ aimed to determine the clinical and biochemical characteristics of T1DM at presentation in children younger than 15 years in Croatia during a 9-year period. During the study period, 692 children were diagnosed with type $1 \mathrm{DM}$. Polydipsia (96.7\%), polyuria $(96.05 \%)$, and weight loss $(82.7 \%)$ were the most frequent symptoms anticipating disease detection. Enuresis was recorded in $11.55 \%$. Additionally, Chen and colleagues ${ }^{(12)}$ conducted a retrospective study in order to review the management experience of T1DM patients in a single center. From January 2004 to June 2015. 52 newly diagnosed diabetic children younger than 6 years who had regular follow-up for $>1$ year were enrolled, as well as 94 older diabetic children for comparison. The most common symptoms and signs were polyuria, polydipsia, dry lips, weight loss, and nocturia. Likewise, Gómez and colleagues (13) \{Formatting Citation\} aimed to determine incidence, mortality, and clinical status of youth with diabetes at the Centro Vivir con Diabetes, Cochabamba, Bolivia, Results. Over 12.2 years, 144 cases with T1DM were diagnosed. The most common presentation was polyuria/polydipsia, followed by weight loss, nocturia, and vomiting. 
In our cohort, $24 \%$ of the patients had history of T1DM and $47 \%$ had a history of other autoimmune diseases. The vast majority of the patients had a family history of T2DM (59\%). There were statistically significant associations between age group and family history of T1DM $(\mathrm{p}<0.001)$ and consanguinity $(p<0.001)$. Familial clustering of type 1 diabetes is a conspicuous feature; the risk of developing T1DM is $8-15$-fold higher in first-degree relatives and twofold in second-degree relatives. Despite this, the vast majority of children were diagnosed with the sporadic form of diabetes. The proportion of children with an affected first-degree relative at the time of diagnosis is $\sim 10-12 \%$, and after decades of follow-up, this frequency increased to > $20 \%{ }^{(14)}$. In agreement with our findings, Alhonen and colleagues ${ }^{(15)}$ aimed to determine the extended family history of diabetes or autoimmune diseases in families with and without children having T1MD. Three hundred case families and 381 control families were interviewed using structured questionnaires. The proportion of case children having at least one relative with T1DM outside the nuclear family was higher than that of control children (50.3 vs. $31.8 \%, P<0.001)$. Other autoimmune diseases occurred more frequently among the case children (9.7 vs. $1.1 \%, P<0.001)$, in the case nuclear families (22.0 vs. $12.9 \%, P=0.002)$ and in relatives outside the case nuclear family (72.0 vs. $62.2 \%, P=0.007$ ).

Quinn and colleagues (16) aimed to characterize the prodrome, presentation, family history, and biochemical status at diagnosis of T1DM in children under age 6 years. This was a retrospective chart review of patients hospitalized at diagnosis with T1DM from 1990 to 1999 in a children's hospital. A total of 247 children were hospitalized. A total of $9 \%$ of the subjects had a first-degree relative with T1DM. Similarly, other reports demonstrated lower rate of family history of T1DM. For example, Parkkola and colleagues ${ }^{(17)}$ aimed to determine the frequency of newly diagnosed diabetic children with first- and second-degree relatives affected by T1DM. Children $(n=1,488)$ with T1DM diagnosed under 15 years of age were included in a cross-sectional study from the Finnish Pediatric Diabetes Register. A total of $12.2 \%$ of the subjects had a first-degree relative with T1DM (father $6.2 \%$, mother $3.2 \%$, and sibling $4.8 \%$ ) and $11.9 \%$ had an affected second-degree relative. The difference between our findings and the abovementioned studies can be explained by the difference in population's characteristics. It was reported that the characteristics of T1DM varies significantly by geographical region ${ }^{(\mathbf{1})}$.

In the present study, disproportionate maternal influences on the risk of T1DM suggests that critical disease-inducing environmental events operate very early, even in the utero. A number of maternal-related events are associated with an increased disease risk in children but not in adults ${ }^{(18)}$. We found that, in terms of obstetric history, $76 \%$ of the mothers delivered by CS, $12 \%$ of them had history of preeclampsia and $13 \%$ had a history of gestational diabetes. On the other hand, $13 \%$ and $29 \%$ of the mothers had a history of infectious diseases and use of antibiotics, respectively. There were no statistically significant associations between age group and preeclampsia ( $\mathrm{p}=0.33$ ), gestational diabetes and use of insulin $(\mathrm{p}=0.67)$, infectious diseases $(p=0.91)$, use of antibiotic ( $p$ $=0.26$ ), use of antihypertensive ( $\mathrm{p}=0.22)$, and mode of delivery $(\mathrm{p}=0.067)$. In agreement with our findings, Majeed and colleagues ${ }^{(4)}$ carried out a case-control to determine the potential maternal, neonatal and early childhood risk factors for T1DM in children and adolescents in Basrah. A total of 96 diabetic patients who have been admitted to the pediatric wards at 3 main hospitals in Basrah. Family history of type 1 diabetes mellitus and thyroid diseases in first and second-degree relatives was found to be an independent risk factor for type 1 diabetes mellitus, ( $p$ $<0.001$ ). Regarding maternal habits and illnesses during pregnancy, the study revealed that tea drinking during pregnancy is a risk factor for type 1 diabetes mellitus in their offspring, $(\mathrm{p}<0.05)$. In addition, maternal pre-eclampsia and infections were found to be significant risk factor for type 1 diabetes mellitus, $(\mathrm{p}<0.001)$. Similarly, Waernbaum and colleagues (19) used a large, nationwide, prospective database to further clarify and analyse the associations between perinatal factors and the subsequent risk for childhood-onset T1DM using a case-control design. The Swedish Childhood Diabetes Register was linked to the Swedish Medical Birth Register and National Patient Register, and 14,949 cases with T1DM born from the start of the Medical Birth Register in 1973 to 2013. In multivariate analysis, there were small but statistically significant associations between higher birthweight $\mathrm{z}$ score, delivery by Caesarean section, premature rupture of membranes and maternal urinary tract infection during pregnancy and the subsequent risk of childhood-onset T1DM. Cardwell and colleagues (20) investigated the evidence of an increased risk of childhood-onset T1DM in children born by Caesarean section by systematically reviewing the published literature and performing a meta-analysis with adjustment for recognized confounders. Twenty studies were identified. Overall, there was a significant increase in the risk of type 1 diabetes in children born by Caesarean section.

In the present study, $15 \%$ of the patients were preterm and $60 \%$ had a history of respiratory diseases. In addition, $80 \%$ had a history of Jaundice and $45 \%$ had a history of infectious diseases. There were no statistically significant associations between age group and preterm $(\mathrm{p}=0.58)$, respiratory diseases $(\mathrm{p}=0.9)$, 
jaundice ( $\mathrm{p}=0.52)$, and infectious diseases $(\mathrm{p}=0.91)$. In line with these findings, Majeed and colleagues ${ }^{(4)}$ demonstrated that neonatal infections, eczema and rhinitis during infancy were also significantly associated with development of type 1 diabetes mellitus. In contrary, Roberts and Harrild (21) reported no evidence of statistically significant associations between T1DM and birth weight, jaundice, phototherapy, breast feeding, admission to neonatal unit and Apgar score $(\mathrm{P}>0.05)$. Moreover, Waernbaum and colleagues (19) showed no association of childhood-onset type 1 diabetes with maternal-child blood-group incompatibility, maternal pre-eclampsia, perinatal infections or treatment of the newborn with phototherapy for neonatal jaundice. The proportion of children with neonatal jaundice was significantly higher in the 1973-1982 birth cohort compared to later cohorts. Again, the difference between our findings and the abovementioned studies can be explained by the difference in population's characteristics. It was reported that the characteristics of T1DM varies significantly by geographical region (1).

In the present study, 9\% and $20 \%$ of the patients had history of measles and mumps, respectively. In addition, $13 \%$ had history of varicella. There were no statistically significant associations between age group and measles $(\mathrm{p}=0.77)$ and varicella ( $p=0.95$ ). In contrary, there was statistically significant associations between age group and mumps ( $\mathrm{p}=0.03)$. Infection is one of the most likely candidates that is involved in the development of T1DM. There is, however, surprisingly little direct evidence for infections causing diabetes on a population basis. Infection may be involved at two stages in the development of T1DM, first, as initiating factors which start the diabetogenic process and second, as precipitating factors which non-specifically precipitate clinical diabetes ${ }^{(22)}$. In line with our findings, Yang and colleagues ${ }^{(22)}$ investigated the role of infectious diseases in the development of T1DM. A case-crossover design was employed. Information on infectious diseases during $407 \mathrm{~d}$ before the onset of T1DM was collected from medical records and parents' interviews for 260 patients in Chinese T1DM registry. Forty-eight (18\%) patients were reported to have infectious diseases during this period based on medical records and interviews with parents. The relative risk of T1DM onset was markedly elevated to $10.1(5.6,17.9)$ immediately after infectious diseases, suggesting the role of infections as a precipitator.

In our cohort, $80 \%$ of the patients had history of introduction of cow milk before 1 year of life and $34 \%$ of the patients received breastfeeding. Various environmental factors have been implicated and included pre- and post-natal exposures. It is argued that cows' milk protein is a key environmental trigger that may explain a significant rise in type 1 diabetes and the different prevalence rates ${ }^{(23)}$. On the other hand, some epidemiological studies have shown a protective effect of breastfeeding against T1DM, whereas others have found opposite results ${ }^{(24)}$.

\section{CONCLUSION}

In conclusion, Egyptian children with T1DM had wide range of genetics, environmental, maternal, and neonatal risk factors that may have contributed to the development of T1DM. In our study, we found that Egyptian T1DM patients had higher rate of positive family history of diabetes as well as other autoimmune diseases. In addition, they had high rate of maternal risk factors (delivered by CS, preeclampsia, gestational diabetes, history of infectious diseases, and use of antibiotics), neonatal risk factors (preterm, respiratory diseases, history of Jaundice and infectious diseases), and cow milk use before one year. In addition, they have low rate of exclusive breastfeeding. These findings are very important as it confirms the need for interventions to minimize the exposure to those risk factors in genetically-susceptible patients. Nevertheless, further studies with rigorous design, large sample size and multiregional cooperation are required.

\section{Recommendations}

- Egyptian children with T1DM had wide range of genetics, environmental, maternal, and neonatal risk factors that may have contributed to the development of T1DM. Therefore, interventions that aim to minimize the exposure to those risk factors are recommended in genetically susceptible patients.

\section{REFERENCES}

1. El-Ziny M, Salem N, El-Hawary A et al. (2014): Epidemiology of childhood type 1 diabetes mellitus in Nile Delta, northern Egypt - a retrospective study. J Clin Res Pediatr Endocrinol., 6: 9-15.

2. Katsarou A, Gudbjörnsdottir S, Rawshani A et al. (2017): Type 1 diabetes mellitus. Nat Rev Dis Prim., 3: 17016-18.

3. Wu Y, Ding Y, Gao J et al. (2013): Risk factors and primary prevention trials for type 1 diabetes. Int J Biol Sci., 9: 666-79.

4. Majeed A, Hassan M (2011): Risk factors for type 1 diabetes mellitus among children and adolescents in Basrah. Oman Med J., 26: 189-95.

5. Atkinson M, Von Herrath M, Powers A et al. (2015): Current concepts on the pathogenesis of type 1 diabetesconsiderations for attempts to prevent and reverse the disease. Diabetes Care, 38: 979-88.

6. Gregory J, Moore D, Simmons J (2013): Type 1 diabetes mellitus. Pediatr Rev., 34: 203-15.

7. Kautzky-Willer A, Harreiter J, Pacini G (2016): Sex and gender differences in risk, pathophysiology and 
complications of type 2 diabetes mellitus. Endocr Rev., 37: 278-316.

8. Koch L (2011): Diabetes: Rage links genes and environmental factors in type 1 diabetes mellitus. Nat Rev Endocrinol., 7: 249-53.

9. Benoit S, Hora I, Albright A et al. (2019): New directions in incidence and prevalence of diagnosed diabetes in the USA. BMJ Open Diabetes Res Care, 7: e000657. doi:10.1136/bmjdrc-2019-000657.

10. Al-Yaarubi S, Ullah I, Sharef S et al. (2014): Demographic and clinical characteristics of type 1 diabetes mellitus in omani children - single center experience. Oman Med J., 29: 119-22.

11. Stipancic G, Sepec M, La Grasta S et al. (2011): Clinical characteristics at presentation of type 1 diabetes mellitus in children younger than 15 years in Croatia. $\mathbf{J}$ Pediatr Endocrinol Metab., 24: 665-70.

12. Chen Y, Tung Y, Liu S et al. (2017): Clinical characteristics of type 1 diabetes mellitus in Taiwanese children aged younger than 6 years: A single-center experience. J Formos Med Assoc., 116: 340-4.

13. Gómez E, Gregory G, Castrati $\mathrm{N}$ et al. (2017): Incidence and Mortality Rates and Clinical Characteristics of Type 1 Diabetes among Children and Young Adults in Cochabamba, Bolivia. J Diabetes Res., 2017: 8454757.

14. Simmons K (2015): Type 1 diabetes: A predictable disease. World J Diabetes, 6 (3): 380-90.

15. Alhonen S, Korhonen S, Tapanainen P et al. (2011): Extended family history of diabetes and autoimmune diseases in children with and without type 1 diabetes. Diabetes Care, 34: 115-7.
16. Quinn M, Fleischman A, Rosner B et al. (2006): Characteristics at diagnosis of type 1 diabetes in children younger than 6 years. J Pediatr., 148: 366-71.

17. Parkkola A, Härkönen T, Ryhänen S et al. (2013): Extended family history of type 1 diabetes and phenotype and genotype of newly diagnosed children. Diabetes Care, 36: 348-54.

18. Leslie R, Castelli M (2004): Age-dependent influences on the origins of autoimmune diabetes: Evidence and implications. Diabetes, 53: 3033-40.

19. Waernbaum I, Dahlquist G, Lind T (2019): Perinatal risk factors for type 1 diabetes revisited: a populationbased register study. Diabetologia, 62: 1173-84.

20. Cardwell C, Stene L, Joner G et al. (2008): Caesarean section is associated with an increased risk of childhoodonset type 1 diabetes mellitus: A meta-analysis of observational studies. Diabetologia, 51: 726-35.

21. Robertson L, Harrild K (2010): Maternal and neonatal risk factors for childhood type 1 diabetes: A matched case-control study. BMC Public Health, 10: 281.

22. Yang Z, Zhou F, Dorman J et al. (2006): Association between infectious diseases and type 1 diabetes: A casecrossover study. Pediatr Diabetes, 7: 146-52.

23. Chia J, McRae J, Kukuljan S et al. (2017): A1 betacasein milk protein and other environmental predisposing factors for type 1 diabetes. Nutr Diabetes, 7 (5): 274-76.

24. Alves J, Figueiroa J, Meneses $\mathrm{J}$ et al. (2012): Breastfeeding protects against type 1 diabetes mellitus: A case-sibling study. Breastfeed Med., 7: 25-8. 